\title{
Conjuring Materialities, Brewing Legal Times
}

\section{Emily Grabham, Brewing Legal Times: Things, Form, and the Enactment of Law, University of Toronto Press, Toronto, 2016, 216 pp, \$41.25, ISBN:978-1-4426-4605-6}

\section{Rebecca Coleman ${ }^{1}$}

Published online: 13 November 2018

(c) The Author(s) 2018

Emily Grabham's book, Brewing Legal Times: Things, Form, and the Enactment of Law (2016) invites its reader to consider the ways in which temporality is made in and through specific relations and materials: paper documents, verbal debates, fleshy bodies, viruses, to name but a few. Time then, Grabham reminds us, is not a vacuum or backdrop to life but is actively made, and is constitutive of life and living. Grabham describes the dynamism and constitutive qualities of time as 'brewed through changing relationships of humans and material forms' (2016: 14). Her argument is that legal time is brewed in these ways; brewing capturing how '[t]ime is material, apparent, and often close at hand, conjured at least partly through the things we use when we "do law" (2016: 14).

There is much that could be unpacked and developed from Grabham's argument, the theoretical traditions she brings together, and the illuminating examples that she writes compellingly about. In this short response to her book, ${ }^{1}$ my focus is on two inter-related aspects of the argument that '[t]ime is material, apparent, and often close at hand, conjured at least partly through the things we use when we "do law" (2016: 14). One is the materiality of time, and the other is the notion that time is 'conjured'. In concentrating on these two aspects, my intention is not so much to summarise the book but to take off from it, and to put it in dialogue with what I see as some commonalities or reverberations with recent work in the new materialisms (some of which Grabham also discusses; see for example pp. 29-31).

\footnotetext{
1 This review was first presented at a book forum on Grabham's Brewing Legal Times hosted by the Centre for Law and Society in a Global Context, School of Law, Queen Mary University of London, on 7 February 2018.
}

Rebecca Coleman

rebecca.coleman@gold.ac.uk

1 Goldsmiths, University of London, London, UK 


\section{Materials, Materiality, Time}

On the materiality of time, Grabham argues that the materials through which law is practised can themselves be understood as brewing time. As a range of different scholars are exploring, it is not only humans that have agency, but things or objects as well (see e.g. Barad 2007; Grosz 2000; Bennett 2010). What is less well worked through are the temporalities of this agency, and it is here, I think, that Grabham's book offers novel and important insights. If things have agency, the materials through which law is done create and regulate legal time. One example of Grabham's point on this is from Chapter 4, 'Transition', which explores the materials involved in the Gender Recognition Act (2005), and how they produce specific temporalities of transitioning for transgender people in the UK.

The GRA enables people to gain legal status for their acquired gender after a period where they transition from one gender to another. Under this Act, transgender people apply to the Gender Recognition Panel for a Gender Recognition Certificate. To be successful, they must provide evidence of a successful transition, and among other things, signal their intention to remain living in the acquired gender until death. Grabham carefully unpacks how the material experience of a body transitioning becomes a specifically temporal legal 'thing', in part through legal materials. Here, then, materiality encompasses both the human body that in various ways changes through a gender transition, and the things through which a transition is legally accepted as successful. In particular, she analyses the documents via which the debates in the House of Commons and House of Lords about the GRA are recorded, paying attention to the significance of the acquired gender lasting 'until death'. Opponents of the Bill directed a lot of attention to this particular aspect of it, as they found it problematic that it left open the possibility that transgender people might reverse (once or more) their transition. In the words of the Conservative Lord Norman Tebbit, this made the Bill 'an objectionable farce' (2016: 128).

While it might be tempting to see the category of 'until death' as indicating permanence-that the transition will be stable and eternal-for proponents of the Bill it indicates a distinct temporal state, where the intention to live in the acquired gender is taken seriously but is not necessarily seen as unchanging or static. That is, upon submitting the correct evidence to the Gender Recognition Panel, a transgender person's legal status could be changed again. Intention, then, is an indication of what one anticipates and expects, but is not necessarily permanent. Applicants must provide a statutory declaration of this intention as 'a means of asserting the truth of a fact when it is not possible to bring other evidence' (2016: 135).

The statutory declaration of the intention to live in the acquired gender until death that is indicated on a bureaucratic form is one part of how a gender transition is deemed successful and how an acquired gender is granted legal status. The form, then, is a specific material via which a specific legal temporality, and a specific person, is made. As Grabham puts it, "transition in UK law is inseparable from the statutory declaration form that the GRA requires as evidence of 
intention to remain in gender "until death" (2016: 120). In other words, the form functions to ratify the legal status of an acquired gender. Put yet another way, the materiality of the transgender person's body is constituted in part through the materiality of the statutory declaration form. The statutory declaration form functions temporally as a projection into the future (' $I$ intend to remain in this gender') while at the same time this projection is not stable. Transitioning, then, framed through the 'to death clause', is at once deemed 'successful', and hence is in some way stabilised, and remains open-ended or in process, in that it may not be permanent. Or, as Grabham puts it, the form 'achieve[s] a temporal horizon that was discursively closed (enough), yet technically open' (2016: 135).

Materiality, therefore, is a wide-ranging category, which can encompass things and objects such as legal forms and documents, and the fleshy material of the human body. More than this, multiple and perhaps disparate materialities are in constitutive relations; the acquired gender of a transgender person is made legible through the parliamentary debates and legal forms, for example. With such an understanding of materiality, it is necessary, Grabham argues, to consider temporality. As I noted earlier, Grabham's notion of 'brewing' is that relations between various materialities are changing and transformative. That is, these relationships are always in process, always becoming. Materiality, then, is always in the process of materialisation.

One important aspect of the new materialisms is an understanding of the world as open-ended, and with the potential to become different/ly. Materialities are future-oriented temporalisations, where temporality is non-linear; the future is not that which inevitably unfolds from the past and present in a causal fashion (as the capacity for gender reversals indicates), but is better understood as a virtual possibility that may, and may not, be actualised (e.g. Grosz 2000). Crucial here is that, as Karen Barad notes, 'the future is radically open at every turn' (2007: 178) — that is, the agency of things designates the capacity for change and transformation. However, what also needs noting is the ways in which this radical openness may not be actualised, and that it may be difficult for some transformations to take hold.

This aspect of the new materialisms resonates with Grabham's argument. For example, relatively early in the book, Grabham very neatly presents one summary of her argument. She writes,

If we understand that our legal actions, arguments, documents, classification systems, mistakes, and innovations have temporalizing effects, and do not merely exist 'in time', we can also understand these temporalities, things, and effects as inherently political because they are world-making, and not merely passive (2016: 15).

The example of gender transitioning demonstrates that 'temporalising effects' are 'inherently political' - political with both a capital and small 'p'. Grabham's argument that politics is about world-making brings me to the second point I'd like to consider a little; that time is 'conjured at least partly through the things we use when we "do law", (2016: 14). 


\section{Conjuring, Ethics, Enchantment and Wonder}

One of the contributions that Grabham's book makes to law and the social sciences more generally is to turn our attention to the often mundane and overlooked materials through which time is made. The notion that time is 'conjured' encourages us to look at the creative potential of things (and here creative points to the agency and constitutive qualities of things, rather than necessarily being 'good'). Grabham's notion of conjuring can be understood as methodological in its widest sense, in that it is as much about an approach to understanding law as it is about the content of her argument.

Again, there are helpful connections to be made between the book and recent feminist new materialisms work, and here especially with Bennett's (2001) work on enchantment. Bennett's argument about enchantment is explicated through a focus on modernity, which is commonly framed as disenchanted; technologies, commercialisation and bureaucracy have dampened and diminished the capacity for wonder, awe, enchantment. Against this framing of modern life, Bennett demonstrates how enchantment remains present in various forms of sociality. 'To be enchanted', she writes, 'is to be struck and shaken by the extraordinary that lives amid the familiar and the everyday' (2001: 4). In other words, enchantment 'lives' and can be encountered as an affective force in habitual and habituated spaces and times. Moreover, Bennett explains,

Enchantment is something that we encounter, that hits us, but it is also a comportment that can be fostered through deliberate strategies. One of these strategies might be to give greater expression to the sense of play, another to hone sensory receptivity to the marvellous specificity of things (2001: 4).

In its focus on the agency of various human and non-human materials, and the ways in which time is created through these agencies, Grabham's book pays attention to both of these senses of enchantment. It responds to those familiar materials that seem most enchanted, whether they be legal actions, debates, documents, classification systems, mistakes, and innovations. And it attempts to remain open to 'the marvellous specificity of things' in the ways in which specific things brew specific temporalities.

Bennett's concept of enchantment is linked with her proposal of wonder as an ethical way of relating to the world: 'if enchantment can foster an ethically laudable generosity of spirit, then the cultivation of an eye for the wonderful becomes something like an academic duty' (2001: 10). Bennett frames this understanding of enchantment as an academic and ethical duty in terms of a generosity to others, whether they be human or non-human. Such a project may be understood as political and ethical in attending to what worlds are given life. As Karen Barad puts it, ethics are 'embodied in the very worlding of the world' (Barad 2007: 160), and as Haraway argues, 'it matters what matters we use to think other matters with' (2016: 12). Grabham's argument that materials and their temporalizing effects are 'inherently political because they are world-making' draws attention to the ethics involved in exploring the, often mundane and overlooked, 
things that both populate daily lives and, more significantly, make or constitute these lives. Through examining the materialities via which other materialities are made, Grabham's book demonstrates that it matters how worlds are worlded, because specific worlds are made. Her book therefore attends to the materialities via which world-making currently occurs, and provides pointers as to how other worlds may be made possible through other materialities.

Open Access This article is distributed under the terms of the Creative Commons Attribution 4.0 International License (http://creativecommons.org/licenses/by/4.0/), which permits unrestricted use, distribution, and reproduction in any medium, provided you give appropriate credit to the original author(s) and the source, provide a link to the Creative Commons license, and indicate if changes were made. Open access publication was made possible by financial support from Goldsmiths, University of London.

\section{References}

Barad, Karen. 2007. Meeting the Universe Halfway: Quantum Physics and the Entanglement of Matter and Meaning. Durham, New York: Duke University Press.

Bennett, Jane. 2001. The Enchantment of Everyday Life: Attachments, Crossings, and Ethics. Princeton: Princeton University Press.

Bennett, Jane. 2010. Vibrant Matter: A Political Ecology of Things. Durham, New York: Duke University Press.

Grabham, Emily. 2016. Brewing Legal Times: Things, Form, and the Enactment of Law. Toronto: University of Toronto Press.

Grosz, Elizabeth. 2000. Deleuze's Bergson: Duration, the Virtual and a Politics of the Future. In Deleuze and Feminist Theory, ed. C. Colebrook and I. Buchanan, 214-234. Edinburgh: Edinburgh University Press.

Haraway, Donna. 2016. Staying with the Trouble: Making Kin in the Chthulucene. Durham, London: Duke University Press. 